after addition of hæmin may be due to the formation of globin dimers (or higher polymers) in which the monomers are held together by hæmin bridges so that the total number of protein particles in the interface decreases; this would result in a lower pressure of the interfacial protein film. Both phenomena may be responsible for the enormous drop in the interfacial pressure shown in Fig. 1. Whatever the interpretation may be, the experiments reveal a highly specific reaction between globin and hæmin molecules in the $p$-xylene/water interface.

$$
\begin{aligned}
& \text { F. Haurowitz } \\
& \text { M. Dicks } \\
& \text { D. G. Therriault }
\end{aligned}
$$

Department of Chemistry,

Indiana University,

Bloomington, Indiana.

$$
\text { April } 25 .
$$

'Haurowitz, F., Boacher, P., Dicks, M., and Therriault, D., drch Biochem. Biophys., 59, 52 (1955).

'Anson, M., and Mirsky, A. E., J. Gen. Physiol., 13, 121, 133, 469 $(1930)$.

${ }^{3}$ Zuidema, H. IT., and Waters, G. W., Indust. Eng. Chem., Anal. edit. 13, 312 (1941).

'Hill, R., and Holden, F., Biochem. J., 20,1326 (1926). Anson, M. and ifirsky, A. E., J. Physiol., 60, 50 (1925). Adair, G. S., Elkes I. I., Frazer, A. C., Schulman, J. H., and Stewart, H. C., J. (1926).

\section{Cholinesterase Content of the Dog's Lymphocytes and Polynuclears}

I HAVE already indicated the presence of cholin. esterase in dog's, rabbit's and man's white blood cells ${ }^{1}$. The cholinesterase of the leucocytes is similar to that of the erythrocytes. A technique I have recently described ${ }^{2}$ was used for the separation of the various morphological forms of white cells. Since then I have studied the cholinesterase content of dog lymphocytes and polynuclears separately (see Table 1). Determination of the enzyme was based on Michel's method ${ }^{3}$. Table 1. ChOLINESTERASE CONTRNT OF DOG'S POLYNUChEARS AND LYMPHOCYTES EXPRESSED IN $\Delta p H /$ HR. THE VAL

$\begin{array}{cccccc}\begin{array}{c}\text { Polv- } \\ \text { nuclears } \\ \text { (per } \\ \text { mm.) }\end{array} & \begin{array}{c}\text { Poly- } \\ \text { nuclear } \\ \text { solution } \\ \text { (ml.) }\end{array} & \begin{array}{c}\text { Lympho- } \\ \text { cytes } \\ \text { (per } \\ \text { mm.) }\end{array} & \begin{array}{c}\text { Lympho- } \\ \text { cyte } \\ \text { solution } \\ \text { (ml.) }\end{array} & \begin{array}{c}\text { Polynuclear } \\ \text { cholin- } \\ \text { esterase }\end{array} & \begin{array}{c}\text { Lymphocyte } \\ \text { cholin- } \\ \text { esterase }\end{array} \\ 8,300 & 2 & 4,600 & 8.1 & 0.825 & 0.500\end{array}$

The cholinesterase activity is inhibited by a high concentration $(0.06 \mathrm{gm}$.) of the substrate acetylcholine, whereas it is high at the lower $(0.004 \mathrm{gm}$. concentration ('Table 2). It is therefore suggested that the enzyme may be one of the specific cholin esterases. This type of enzyme is found in both forms studied.

\section{Effects of Carbon Sources and Base Analogues of Nucleic Acid on the Formation of Bacterial Amylase}

A WASHED suspension of Bacillus amylotiquefaciens Fukumoto cells ${ }^{1}$, which is a strain of Bacillus subtilis that has been used for the industrial production of bacterial $\alpha$-amylase, secretes a small but distinct amount of amylase when shaken aerobically in the presence of phosphate. Under the same conditions, the addition of a sugar or a salt of an organic acid as the carbon source causes a great increase in the formation of amylase without any addition of nitrogen source ${ }^{2}$. Since the enzyme detected in the autolysate or lysozyme-lysed solution of the bacterial cells is very small, it seems to be certain that the amylase appearing in the cell suspension did not pre-exist in the bacterial cells, but is newly formed and secreted by the cells. In this experiment, however, the amount of enzyme formed differs markedly according to the type of carbon source ${ }^{3}$. As seen in Table 1, there

Table 1. Amylase Formation and Respiration of the Chli

\begin{tabular}{|c|c|c|c|c|}
\hline $\begin{array}{l}\text { Carbon } \\
\text { sources }\end{array}$ & $\begin{array}{l}\text { Amylase } \\
\text { activity } \\
\text { per ml.* }\end{array}$ & $Q_{0} \dagger$ & $\begin{array}{l}\text { Carbon } \\
\text { sources }\end{array}$ & $\begin{array}{l}\text { Amylase } \\
\text { activity } \\
\text { per ml." }\end{array}$ \\
\hline $\begin{array}{l}\text { None } \\
\text { Pyruvate } \\
\text { Gluconate } \\
\text { Xylose } \\
\text { Arabinose } \\
\text { Ribose }\end{array}$ & $\begin{array}{r}4 \cdot 0 \\
15 \cdot 0 \\
15 \cdot 5 \\
2 \cdot 7 \\
19 \cdot 5 \\
20 \cdot 5 \\
3.8\end{array}$ & $\begin{array}{l}16 \\
91 \\
55 \\
15 \\
62 \\
67 \\
92\end{array}$ & $\begin{array}{l}\text { Mannose } \\
\text { Galactose } \\
\text { Maltose } \\
\text { Sucrose } \\
\text { Lactose } \\
\text { Soluble starch }\end{array}$ & $\begin{array}{r}5 \cdot 3 \\
21 \cdot 5 \\
13 \cdot 5 \\
4 \cdot 0 \\
24 \cdot 0 \\
17 \cdot 5\end{array}$ \\
\hline
\end{tabular}
SUSPENSION ON VARIOUS KINDS OF CARBON Sources

$46 \mathrm{mgm}$. of cells as dry matter, $M / 10$ phosphate, 0.5 per cent sugar or $M / 30$ organic acid (sodium salt); total vol., $15 \mathrm{ml}$.; $p \mathrm{H} 6 \cdot 8,10 \mathrm{hr}$.

* The activity of $1 \mu \mathrm{gm}$. of crystaline bacterial amylase is taken as one unit (ref. 4).

t Determined after $2 \mathrm{hr}$, shaking.

is no clear adaptive relationship between the formation of enzyme and the carbon sources, and also the amount of amylase formed is not in any way parallel to the respiration activity of the cell, which is related to the carbon sources. 'This characteristic effect of carbon source on enzyme formation is almost always observed, regardless of the type of carbon source on which the cells are grown. Sugars such as glucose and fructose are not only ineffective but may be even somewhat inhibitory, and adding them to other carbon sources which are available for enzyme formation completely nullifies their effect. This diauxic effect ${ }^{5}$ appears almost immediately after the addition of these sugars, and remains constant during the course of the experiment, although no metabolic product inhibitory to enzyme formation has yet been

\begin{tabular}{|c|c|c|c|c|c|c|c|}
\hline $\begin{array}{l}\text { Polynuclears } \\
\text { (per min.) }\end{array}$ & $\begin{array}{l}\text { Polynuclear } \\
\text { solution } \\
\text { (inl.) }\end{array}$ & $\underset{\text { (per mm.) }}{\text { Lymphocytes }}$ & $\begin{array}{l}\text { Lymphocyte } \\
\text { solution } \\
\text { (inl.) }\end{array}$ & $\begin{array}{l}\text { Polynuclear } \\
\text { cholinesterase } \\
(0.004)\end{array}$ & $\begin{array}{c}\text { Polynuclear } \\
\text { cholinesterase } \\
(0 \cdot 06)\end{array}$ & $\begin{array}{c}\text { Lymphocyte } \\
\text { cholinesterase } \\
(0.004)\end{array}$ & $\begin{array}{l}\text { Lymphocyte } \\
\text { cholinesterase } \\
(0.06)\end{array}$ \\
\hline 13,800 & 7 & 8,800 & $20 \cdot 1$ & $1 \cdot 063$ & $0 \cdot 246$ & $1 \cdot 300$ & 0.386 \\
\hline
\end{tabular}
detected in the cell suspension system. However,

Table 2. Cholnesterase Content of Dog's Polyndclears and Lymphocytes in $\triangle p$ H/hr. Note Greater Valdes at $0 \cdot 004$ GM. S UB-

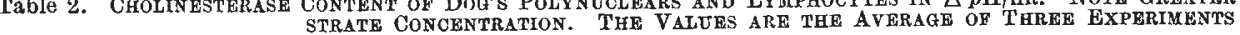

Further work on these lines is being undertaken; details of the results will be published elsewhere.

Laboratory of Physiology, A. J. Philitpro

University of Athens. April 2.

1 Philippu, A. J., Amer. J. Physiol., 181, 145 (1956).

2 Philippu, A. J.. Blood, 11. 1041 (1956).

Michel, H. O., J, Lab. Clin. Med., 34, 1564 (1949). even on a glucose carbon source, good formation of the enzyme occurs to the same extent as from a galactose carbon source, if the glucose concentration is maintained at a very low level (about $0.01-0.02$ per cent).

Considering these divergent effects of carbon sources on enzyme formation, the following facts seem to be very suggestive. The cells under the experimental conditions indicated in Table 1 secrete 